\title{
Enhancing Ossiointegration And Corrosion Properties of Ti6Al4V Alloy By Coating With Chitosan - Collagen- Hydroxyapatite For Biomedical Applications
}

Adnan M.Mahdi ( $\sim$ ad07802141877@gmail.com )

Wasit university college of science department of physics

Abbas F. Essa

Wasit university college of science department of physics

Mohammed Kh. Khalf

Ministry of science and Technology

\section{Research Article}

Keywords: Strontium hydroxyapatite synthesis, coating surgical implants by dip coating method, coating surgical implants by collagen - chitosan

Posted Date: November 22nd, 2021

DOI: https://doi.org/10.21203/rs.3.rs-1083187/v1

License: (c) (1) This work is licensed under a Creative Commons Attribution 4.0 International License.

Read Full License 


\section{Abstract}

In this research, Ti-6Al-4V alloy samples were coated with $4 \mathrm{gm}$ strontium hydroxyapatite with $2 \mathrm{gm}$ from chitosan and $(2,4,6) \mathrm{gm}$ from collagen and the samples heat treated at $150^{\circ} \mathrm{C}$ in muffle furnace for one hour under air atmosphere. The sample were tested by XRD,FTIR,SEM and corrosion test was also achieved. The samples were immersed in a laboratory prepared simulated body fluid (SBF) solution for two weeks, the samples treated at $150^{\circ} \mathrm{C}$ in muffle furnace for one hour under air atmosphere to get more bonding for new layer. The samples tested by XRD,FTIR,SEM and corrosion test was also achieved after immersing. The sample coated with $6 \mathrm{gm}$ collagen showed maximum growth of hydroxyapatite formed from simulated body fluid SBF and corrosion characteristics was much improved.

\section{Introduction:}

Hydroxyapatite $(\mathrm{HA})\left[\mathrm{Ca}_{10}\left(\mathrm{PO}_{4}\right)_{6}(\mathrm{OH})_{2}\right]$ has been widely studied attributable to the structural, chemical similarities confirmed as the main inorganic constituent of bone and teeth [1]. Conversely, it is well reported that biological hydroxyapatite, which forms the mineral phases of hardened tissues (enamel, dentin and bone), differs from synthetically produced HA and pure. Numerous impurities such as (Mg, F, $\mathrm{Na}, \mathrm{K}$ ) can also naturally founded in occurring bone. As well as to this trace quantities of elements such as $(\mathrm{Sr}, \mathrm{Ba}, \mathrm{Cu})$ are frequently related to biological Hydroxyapatite and may be gotten as substituent's in the hydroxyapatite structure [2]. For that reason, one approach to increase the osteoblastic response of $\mathrm{HA}$ coatings, could be involved the use of strontium substituted hydroxyapatite $\mathrm{SrHA}\left(\mathrm{Ca}_{10-\mathrm{x}} \mathrm{Sr}_{\mathrm{x}}\left(\mathrm{PO}_{4}\right)_{6}\right.$ $\left.(\mathrm{OH})_{2}\right)[3$ and 4]. The extracellular medium of connective tissues denotes a complex alloy of variable members of diverse protein families defining structural integrity and various physiological functions. The most rich proteins in the extracellular matrix are members of the collagen group [ 5]. Collagens were once considered to be a proteins groups with a specific molecular structure with their fibrillar structures contributing to the extracellular scaffolding. Bone as shown in Fig. (1) is a normal two phase organic and inorganic ceramic composite consisting of collagen fibrils with inserted well-ordered inorganic nanocrystalline constituent. The main organic phase of the bone medium is collagen Type I and is veiled by osteoblast cells. The fibrils are bundled together and predominately self-orientate themselves parallel to the load-bearing axis of the bone. Second phase of the medium is the apatite HA, It is the highest inorganic constituent of natural bone, accounting for up to about $65 \%$ by weight of cortical bone [ 6.7 and 8].

Chitosan is the greatest abundant basic biopolymer and is similar to cellulose structur, which is consisted of only one monomer of glucose (Fig. 2) [9]. Chitosan is considered one of the most valuable polymers for biomedical and pharmaceutical applications because of its biocompatibility, antimicrobial, nontoxicity, biodegradability and anti-tumor properties. Nanoparticles, microspheres, hydrogels, films, and fibers are typical chitosan based forms for biomedical and pharmaceutical applications. Examples of such applications include ocular, nasal, oral, parenteral and transdermal drug delivery [10]. 
In this research, strontium hydroyaptite SrHA prepared by wet chemical method, by reacting calcium nitrate $\left(\mathrm{Ca}\left(\left(\mathrm{NO}_{3}\right)_{2} \cdot 4 \mathrm{H}_{2} \mathrm{O}\right)\right.$ and Diammonium hydrogen phosphate $\left(\mathrm{NH}_{4}\right)_{2} \mathrm{HPO}_{4}$. Then Ti6Al4V alloy was coated with composite consisting of SrHA ,collgen and chitosan by dip coating in order to improve the corrosion characteristics and osseointegration with bone. The coated samples was immersed in synthesized simulated body fluid SBF solution which it's component listed in table (1) below for two weeks in order to study the effect of collagen addition on the osseointegration.

Table (1) Chemical composition of synthetic simulated body fluid (SBF) [11].

\begin{tabular}{|lll|}
\hline ITEM & Description & Quantity gm/I \\
\hline 1 & $\mathrm{NaCl}$ & 8.036 \\
\hline 2 & $\mathrm{KCl}$ & 0.225 \\
\hline 3 & $\mathrm{CaCl}_{2}$ & 0.293 \\
\hline 4 & $\mathrm{NaHCO}_{3}$ & 0.352 \\
\hline 5 & $\mathrm{~K}_{2} \mathrm{HPO}_{4} \cdot 3 \mathrm{H}_{2} \mathrm{O}$ & 0.230 \\
\hline 6 & $\mathrm{MgCl}_{2} \cdot 6 \mathrm{H}_{2} \mathrm{O}$ & 0.311 \\
\hline 7 & $\mathrm{Na}_{2} \mathrm{SO}_{4}$ & 0.072 \\
\hline
\end{tabular}

\section{Materials And Methods:}

Strontium substituted hydroxyapatite ( $\mathrm{SrHA}$ ) was prepared by adding $18 \mathrm{gm}$ of calcium nitrate $\mathrm{Ca}\left(\mathrm{NO}_{3}\right)_{2} \cdot 4 \mathrm{H}_{2} \mathrm{O}$ (BDH Chemicals ,England) with $4 \mathrm{gm}$ strontium nitrate $\mathrm{Sr}\left(\mathrm{NO}_{3}\right)_{2}$ (Riedel-de Haen, Germany) to $250 \mathrm{ml}$ dionized water. The solution was mixed using ultrasonic bath for 30 minutes. $20 \mathrm{gm}$ o orthophosphoric acid $85 \%$ (Merck, Germany) was added to $250 \mathrm{ml}$ deionized water and mixed gentle using magnetic stirrer. The phosphoric acid solution was added dropwise to the first mixture for 30 minutes under mixing in the ultrasonic bath. After the addition was complete the mixture in ultrasonic bath was continued for another 30 minutes, then the solution was filtered using filter paper and dried under $80^{\circ} \mathrm{C}$ for $24 \mathrm{hr}$. and then milled in mortar to get fine powder. The fine powder as heat treated at 600 ${ }^{\circ} \mathrm{C}$ for one hour under air atmosphere using muffle furnace. $1 \mathrm{gm}$ of phosphorus pentoxide $\mathrm{P}_{2} \mathrm{O}_{5}(\mathrm{BDH}$, England) was added to $50 \mathrm{ml}$ of absolute ethanol 96\% (scharlau, Espain) and mixed well for $20 \mathrm{~min}$. using magnetic stirrer. $4 \mathrm{gm}$ from prepared strontium hydroxyapatite with $2 \mathrm{gm}$ from chitosan (Shaanxi Co., China) and (2) gm from collagen type I ( Athena Co., USA) was added to the mixture and well mixed for 15 minutes. Ti-6Al-4V alloy samples (20 mm diameter) were grinded using SiC grinding paper grit 500 . The samples were cleaned in ultrasonic bath for 15 minutes twice in ethanol $96 \%$ and once in distilled water for 15 minutes. The samples was dipped in the mixture for $15 \mathrm{sec}$. and dried in the air, then it was dipped again in the mixture for $15 \mathrm{sec}$. to get another layer coating. The coated samples were dried in the 
oven at $90{ }^{\circ} \mathrm{C}$ for $5 \mathrm{hr}$. in the oven under air atmosphere. The dipping procedure was repeated using solution consisting of ( 2 and 4 ) gm collagen individually in each time and $4 \mathrm{gm}$ from prepared strontium hydroxyapatite with $2 \mathrm{gm}$ from chitosan and the coated samples was dried in the oven at $90{ }^{\circ} \mathrm{C}$ for $5 \mathrm{hr}$. in the oven under air atmosphere. The treated samples were tested by XRD, FTIR, SEM and also corrosion test including open circuit potential (OCP), polarization curve (tafel) and electrochemical impedance spectroscopy EIS was done using electrochemical potentiostat (CS 350, China). The samples then were immersed in synthetic simulated body fluid (SBF) solution prepared from chemicals listed in table (1) for two weeks. The samples were heat treated after immersing at $90^{\circ} \mathrm{C}$ for one hour in the oven then tested by, XRD, FTIR, SEM and corrosion test including open circuit potential (OCP), polarization curve (tafel) and electrochemical impedance spectroscopy EIS also done in order to evaluate the results.

\section{Results And Discussion:}

The XRD pattern for samples coated with SrHA with different collagen quantity in Fig. (1) shows the presence of chitosan and collagen at $(2 \theta=18-21)$ with amorphous structure, the two components had

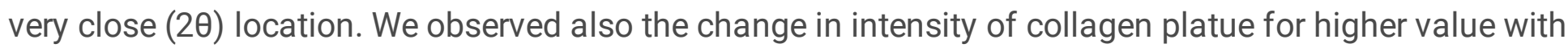
grater quantity. The SrHA obviously was in many locations in the pattern, but we saw that the change in collagen quantity made the peaks of the SrHA with more intensity, i.e the higher quantity of collagen led the SrHA particles to agglomerate, also the collagen led to more particle adhesion on Ti-6Al-4V alloy surface make the SrHA more observed by XRD test. The Ti-6Al-4V peaks also observed in all XRD patterns.

The FTIR spectrum for collagen in Fig. (2) identified the amide A band position at $3484 \mathrm{~cm}^{-1}$, and it associated with the $\mathrm{N}-\mathrm{H}$ stretching vibration. The stretch of $\mathrm{CH}_{2}$, was found at $3071 \mathrm{~cm}^{-1}$ and $2971 \mathrm{~cm}^{-1}$. The amide I band of this collagen was at $1653 \mathrm{~cm}^{-1}$. Amide II bands were found at $1524 \mathrm{~cm}^{-1}$ and 1448 $\mathrm{cm}^{-1}$ indicated $\mathrm{N}-\mathrm{H}$ bending. Amide III bands were found at $1326 \mathrm{~cm}^{-1}$ indicated $\mathrm{C}-\mathrm{H}$ stretching.

The FTIR spectrum for chitosan in Fig. (3) indicated stretching vibrations of $\mathrm{OH}^{-}$groups in the range from $3750 \mathrm{~cm}^{-1}$ to $3000 \mathrm{~cm}^{-1}$ which are overlapped to the stretching vibration of $\mathrm{N}-\mathrm{H}$; and $\mathrm{C}-\mathrm{H}$ bond in $-\mathrm{CH}_{2}$ $\left(v_{1}=2888 \mathrm{~cm}^{-1}\right)$. Peak at $1569 \mathrm{~cm}^{-1}$ was related to the vibrations of carbonyl bonds $(\mathrm{C}=0)$. Bending vibrations of methylene $\mathrm{CH}_{2}$ group were also visible at $v=1375 \mathrm{~cm}^{-1}$. The peak at $1242 \mathrm{~cm}^{-1}$ was related to $v \mathrm{CO}$ in $\mathrm{C}-\mathrm{O}-\mathrm{H}$, and the bands near $(1069-969) \mathrm{cm}^{-1}$ were attributed to $v \mathrm{CO}$ of the ring $\mathrm{C}-\mathrm{O}-\mathrm{C}$.

In the FTIR spectrum for strontium hydroxyapatite - collagen - chitosan in Fig. (4), stretching vibrations of $\mathrm{OH}^{-}$groups in the range from $3460 \mathrm{~cm}^{-1}$ was due to the characteristic $\mathrm{OH}^{-}$vibrations (stretching frequency) of $\mathrm{SrHA}, \mathrm{OH}$ associated with the $\mathrm{N}-\mathrm{H}$ stretching vibration indicated at $3345 \mathrm{~cm}^{-1}$ detect the amide $\mathrm{A}$ band position. Amide $\mathrm{B}$ band, related to the asymmetrical stretch of $\mathrm{CH}_{2}$, was found at 3094 $\mathrm{cm}^{-1}$ and $2964 \mathrm{~cm}^{-1}$ for collagen. $\mathrm{C}-\mathrm{H}$ bond in $-\mathrm{CH}_{2}$ detected at $2873 \mathrm{~cm}^{-1}$. Peak at $1676 \mathrm{~cm}^{-1}$ was related to the vibrations of carbonyl bonds $(\mathrm{C}=0)$ for Amide I in collagen and chitosan. Amide II bands 
were found at $1585 \mathrm{~cm}^{-1}$ and $1486 \mathrm{~cm}^{-1} \mathrm{~N}-\mathrm{H}$ bending. The peak at $1242 \mathrm{~cm}^{-1}$ was related to $v \mathrm{CO}$ in C-O$\mathrm{H}$ for chitosan. The peaks at $(1074,640,602,487) \mathrm{cm}^{-1}$ detected $\mathrm{PO}_{4}{ }^{3-}$ group in SrHA.

The SEM test images in Fig. (6) for Ti-6Al-4V alloy coated with SrHA-chitosan and different quantity of collagen showed clearly the agglomeration of SrHA and collagen with increasing the quantity of collagen.

After immersing in SBF for two weeks the XRD pattern in Fig. (7) showed an obvious peak of hydroxyapatite in all patterns reflected the biomimetic formation of hydroxyapatite from SBF. In the same time the collagen platue disappear because the new hydroxyapatite layer cover the old layer, the agglomeration in particles affect hydroxyapatite formation from SBF, i.e the more quantity collagen leads to more hydroxyapatite formation.

FTIR spectrum for Ti-6Al-4V coated with SrHA- chitosan - collagen after immersing in SBF for two weeks in Fig. (8) indicated stretching vibrations of $\mathrm{OH}^{-}$groups in the range from $3514 \mathrm{~cm}^{-1}$ due to the characteristic $\mathrm{OH}$ vibrations of hydroxyapatite. Amide $\mathrm{B}$ band, related to the asymmetrical stretch of $\mathrm{CH}_{2}$, was found at $3071 \mathrm{~cm}^{-1}$ and $2935 \mathrm{~cm}^{-1}$ for collagen. $\mathrm{C}-\mathrm{H}$ bond in $-\mathrm{CH}_{2}$ detected at $2842 \mathrm{~cm}^{-1}$. Peak at $1669 \mathrm{~cm}^{-1}$ was related to the vibrations of carbonyl bonds $(C=0)$ for Amide I in collagen and chitosan. Amide II bands presented at $1563 \mathrm{~cm}^{-1}$ for $\mathrm{N}-\mathrm{H}$ bending. The absorption band at $1303 \mathrm{~cm}^{-1}$, which was derived from the vibration of the $\mathrm{CO}_{3}{ }^{2-}$ group, was owing to carbonated hydroxyap-atite. The peaks at ( $1044,647,590,495) \mathrm{cm}^{-1}$ detected $\mathrm{PO}_{4}{ }^{3-}$ group in SrHA.

The SEM test image in fig (10) for images for Ti-6Al-4V alloy coated with SrHA- chitosan - collagen after immersing in SBF for two weeks showed the difference in morphology for hydroxyapatite formed from SBF compared with previous fig (6).

\section{Corrosion test:}

The OCP test showed increasing in passivation with increasing collagen quantity as shown in Fig. (11) and table (2). The potential reach to -0.437 volt for sample coated with $6 \mathrm{gm}$ collagen compared with -0.527 for uncoated sample. The polarization curve tafel showed decreasing in corrosion current and so on increasing in corrosion rate as shown in Fig. (12) and table (2). The corrosion rate reach to $1.806 \times$ $10^{-3} \mathrm{mmpy}$ for the sample coated with $6 \mathrm{gm}$ collagen compared with $1.344 \times 10^{-2}$ for uncoated one. This is an indication that the increasing in the collagen quantity positively affected the improvement of the corrosive characteristics.

Table (2) Corrosion characteristics for samples coated with SrHA-collagen- chitosan 


\begin{tabular}{|lllllll|}
\hline ITEM & $\begin{array}{l}\text { Ecor. } \\
\text { volt }\end{array}$ & $\begin{array}{l}\text { Icor. } \\
\mu \text { Amp }\end{array}$ & $\begin{array}{l}\text { Cor. Rate } \\
\text { mmpy }\end{array}$ & a $\beta$ & $\begin{array}{l}\text { OCP } \\
\text { volt }\end{array}$ \\
\hline uncoated & -0.531 & 1.545 & $1.344 \times 10^{-2}$ & 134 & 123 & -0.527 \\
\hline 3 gm chitosan & -0.474 & $7.434 \times 10^{-1}$ & $6.468 \times 10^{-3}$ & 83 & 106 & -0.504 \\
\hline 6 gm chitosan & -0.436 & $5.072 \times 10^{-1}$ & $4.410 \times 10^{-3}$ & 57 & 58 & -0.451 \\
\hline 9 gm chitosan & -0.371 & $2.077 \times 10^{-1}$ & $1.806 \times 10^{-3}$ & 108 & 194 & -0.437 \\
\hline
\end{tabular}

The polarization resistance can be calculated from relation below:

$\mathrm{R}_{\mathrm{p}}=\frac{\mathrm{ba} \times \mathrm{bc}}{2.303(\mathrm{ba}+\mathrm{bc}) \text { icor. }} \ldots . . .(1)$ [12]

Where Rp: polarization resistance, ba: anodic slop, bc: cathodic slop and icor.: corrosion current density $\left(\mathrm{Amp} / \mathrm{cm}^{2}\right)$.

The protection efficiency can be calculated from relation below:

$\mathrm{PE}=\left[1-\frac{\text { icor.cated }}{\text { icor.uncoated }}\right] \times 100$.... (2) [13]

The weight loss can be calculated from Faraday's Law as shown below:

$\mathrm{m}=\frac{\mathrm{ItM}}{\mathrm{ZF}}$

Where $\mathrm{m}=$ mass loss $(\mathrm{gm})$, t: time (sec.).$M$ : molecular weight $(\mathrm{gm} / \mathrm{mol}), \mathrm{z}$ : charge transferred, $\mathrm{F}$ :

Faradays constant and I: current (Amp).

Dividing equation through $\mathrm{t}$ and surface area $\mathrm{A}\left(\mathrm{cm}^{2}\right)$ yields:

Weight loss (W.L.) $=\frac{\mathrm{m}}{\mathrm{tA}}=\frac{\mathrm{iM}}{\mathrm{zF}}$

Table (3) showed the calculated corrosion parameters for samples coated with SrHA- chitosan - collagen. We see the polarization resistance increase with increasing collagen quantity. Rp was $145.04 \mathrm{k} \Omega . \mathrm{cm}^{2}$ for sample coated with $6 \mathrm{gm}$ collagen compared with $18.024 \mathrm{k} \Omega . \mathrm{cm}^{2}$ for uncoated one. Also the protection efficiency increased with increasing collagen quantity from $51.85 \%$ for sample coated with $2 \mathrm{gm}$ collagen to $86.55 \%$ to that coated with $6 \mathrm{gm}$ collagen. The weight loss decreased from $1.656 \mathrm{mdd}$ $\left(\mathrm{mg} \cdot \mathrm{dm}^{-2} \cdot \mathrm{day}^{-1}\right.$ ) for uncoated sample to $0.222 \mathrm{mdd}$ to that coated with $6 \mathrm{gm}$ collagen.

Table (3) Calculated corrosion parameters for samples coated with SrHA- chitosan - collagen. 


\begin{tabular}{|c|c|c|c|}
\hline ITEM & $\mathrm{Rp} k \Omega \cdot \mathrm{cm}^{2}$ & PE \% & W.L. $\operatorname{mdd}\left(\mathrm{mg} \cdot \mathrm{dm}^{-2} \cdot \mathrm{s}^{-1}\right)$ \\
\hline uncoated & 18.024 & --- & 1.656 \\
\hline 2 gm collagen & 27.717 & 51.85 & 0.818 \\
\hline 4gm collagen & 24.611 & 67.17 & 0.543 \\
\hline $6 \mathrm{gm}$ collagen & 145.04 & 86.55 & 0.222 \\
\hline
\end{tabular}

After immersing in SBF for one month the corrosion test indicates that OCP be more passive for all samples even for uncoated one as shown in Fig. (13) and table (4). The OCP be -0.034 volt for sample coated with $6 \mathrm{gm}$ collagen compared with -0.49 volt with that uncoated sample. The corrosion rate decreased as shown in Fig. (14) and table (4) from $9.646 \times 10^{-3} \mathrm{mmpy}$ for uncoated sample to 5.446 $\times 10^{-4} \mathrm{mmpy}$ for that coated with $6 \mathrm{gm}$ collagen.

Table (4) Corrosion characteristics for samples coated with SrHA- chitosan - collagen after immersing in SBF for two weeks.

\begin{tabular}{|lllllll|}
\hline ITEM & $\begin{array}{l}\text { Ecor. } \\
\text { volt }\end{array}$ & $\begin{array}{l}\text { Icor. } \\
\mu A m p\end{array}$ & $\begin{array}{l}\text { Cor. Rate } \\
\text { mmpy }\end{array}$ & a $\beta$ & c $\beta$ & $\begin{array}{l}\text { OCP } \\
\text { volt }\end{array}$ \\
\hline uncoated & -0.486 & 1.109 & $9.646 \times 10^{-3}$ & 132 & 173 & -0.490 \\
\hline 2 gm collagen & -0.286 & $7.100 \times 10^{-1}$ & $6.174 \times 10^{-3}$ & 105 & 128 & -0.326 \\
\hline 4 gm collagen & -0.189 & $2.135 \times 10^{-1}$ & $1.856 \times 10^{-3}$ & 187 & 234 & -0.246 \\
\hline 6 gm collagen & -0.123 & $6.262 \times 10^{-2}$ & $5.446 \times 10^{-4}$ & 158 & 232 & -0.034 \\
\hline
\end{tabular}

The calculated corrosion parameters showed obviously increasing in polarization resistance Rp after immersing in SBF solution for two weeks. Rp increased from $29.315 \mathrm{k} \Omega . \mathrm{cm} 2$ for uncoated sample to 651 $\mathrm{k} \Omega$.cm 2 for that coated with $6 \mathrm{gm}$ collagen. The protection efficiency increased from $35 \%$ for uncoated sample to $94.35 \%$ for that coated with $6 \mathrm{gm}$ collagen. The weight loss decreased also much from 1.168 mdd for uncoated sample to $0.067 \mathrm{mdd}$ for sample coated with $6 \mathrm{gm}$ collagen as shown in table (5).

Table (5) Calculated corrosion parameters for samples coated with SrHA- chitosan - collagen after immersing in SBF solution for two weeks. 


\begin{tabular}{|c|c|c|c|}
\hline ITEM & $\mathrm{Rp} k \Omega . \mathrm{cm}^{2}$ & PE \% & W.L. $\operatorname{mdd}\left(\mathrm{mg} \cdot \mathrm{dm}^{-2} \cdot \mathrm{s}^{-1}\right)$ \\
\hline uncoated & 29.315 & --- & 1.168 \\
\hline $3 \mathrm{gm}$ collagen & 35.276 & 35.97 & 0.761 \\
\hline $6 \mathrm{gm}$ collagen & 241.389 & 80.74 & 0.228 \\
\hline $9 \mathrm{gm}$ collagen & 651.738 & 94.35 & 0.067 \\
\hline
\end{tabular}

\section{EIS test:}

The Nyquist and the Bode plots for Ti6Al4V samples coated with different collagen quantity shows a higher corrosion resistance with increasing collagen quantity from expansion in semicircles with increasing the collagen quantity. The samples with $6 \mathrm{gm}$ collagen in the three Nyquist figures exhibited a greater radius for the capacitive loop indicating that they were provide a better corrosion protection as compared with the other samples as shown in Fig. (15 a and b).

Fig. (16 a and b) represent the equivalent circuit used in data fitting for Ti6Al4V alloy base and coated samples. (Rs) represent solution resistant (electrolyte resistance), (Rcoat) represent coating layer resistance, (Ccoat) represent coating layer capacitance, $(\mathrm{Rdl})$ represent diffusion double layer resistance and $(\mathrm{Cdl})$ represent diffusion double layer capacitance.

We observe from table (6) which represent equivalent circuit fitting data for Ti6Al4V alloy base and coated samples that the coating resistance increased with increasing collagen quantity and reach to $4.985 \mathrm{k} \Omega . \mathrm{cm}^{2}$ for sample coated with $6 \mathrm{gm}$. That occurs because increasing in coating layer thickness and decreasing in porosity. The double layer resistance also increased obviously from $8.668 \mathrm{k} \Omega . \mathrm{cm}^{2}$ for uncoated sample to $18.210 \mathrm{k} \Omega . \mathrm{cm}^{2}$ for that coated with $6 \mathrm{gm}$ collagen. That occurs because the collagen make good agglomeration to coating layer increasing with quantity make a great impediment for the ions to reach the surface and retarding the reaction occur on corroded surface (the corrosion reaction process) lead to decreasing the corrosion rate and improve the resistance to corrosion.

Table (6) Equivalent circuit fitting data for Ti6Al4V alloy base and coated samples 


\begin{tabular}{|c|c|c|c|c|c|c|c|c|c|}
\hline ITEM & $\begin{array}{l}\text { Magnitude } \\
|\mathrm{Z}| 0.01 \mathrm{~Hz} \\
\left(\mathrm{k} \Omega . \mathrm{cm}^{2}\right)\end{array}$ & $\begin{array}{l}\text { Rs } \\
\Omega . \mathrm{cm}^{2}\end{array}$ & $\begin{array}{l}\mathrm{C}_{\text {coat }} \\
\mu \mathrm{F} / \mathrm{cm}^{2}\end{array}$ & $n$ & $\begin{array}{l}R_{\text {coat }} \\
k \Omega . \mathrm{cm}^{2}\end{array}$ & $\begin{array}{l}C_{d l} \\
\mu F / \mathrm{cm}^{2}\end{array}$ & $n$ & $\begin{array}{l}\mathrm{R}_{\mathrm{dl}} \\
\mathrm{k} \Omega . \mathrm{cm}^{2}\end{array}$ & $x^{2}$ \\
\hline uncoat & 3.203 & 454 & - & - & - & 180.1 & 0.53 & 8.668 & 0.15 \\
\hline $\begin{array}{l}2 \mathrm{gm} \\
\text { coll. }\end{array}$ & 13.031 & 425 & 159.7 & 0.48 & 3.215 & 131.4 & 0.49 & 13.720 & 0.13 \\
\hline $\begin{array}{l}4 \mathrm{gm} \\
\text { coll. }\end{array}$ & 16.405 & 383 & 135.1 & 0.53 & 4.396 & 98.8 & 0.51 & 17.266 & 0.14 \\
\hline $\begin{array}{l}6 \mathrm{gm} \\
\text { coll. }\end{array}$ & 21.232 & 324 & 105.7 & 0.49 & 4.985 & 70.5 & 0.48 & 18.210 & 0.13 \\
\hline
\end{tabular}

After immersing the samples in (SBF) solution for two weeks the nyquist and bode plots shows more increasing in resistance, and the expansion in semicircles be higher than before as shown in Fig. (17 a and b) which represent ) nyquist and bode plost for Ti6Al4V samples coated with different collagen quantity after immersing.

Fig. (18) represents the equivalent circuit used in data fitting for Ti6Al4V alloy base and coated samples after immersing in (SBF) solution for two weeks.

We observe from table (7) which represent equivalent circuit fitting data for Ti6Al4V alloy base and coated samples after immersing in (SBF) solution that the coating resistance increased with increasing collagen quantity and reach to $6.728 \mathrm{k} \Omega . \mathrm{cm}^{2}$ for sample coated with $6 \mathrm{gm}$ compared with $3.186 \mathrm{k} \Omega . \mathrm{cm}^{2}$ for uncoated sample. That occurs because increasing in coating layer thickness and decreasing in porosity. The double layer resistance also increased obviously from $9.82 \mathrm{k} \Omega . \mathrm{cm}^{2}$ for uncoated sample to $125.33 \mathrm{k} \Omega . \mathrm{cm}^{2}$ for that coated with $6 \mathrm{gm}$ collagen. That occurs because the new hydroxyapatite layer formed biomematically from (SBF) solution reduce the pore size and make the reach of ions to the substrate surface very difficult, i.e more corrosion resistance.

Table (6) Equivalent circuit fitting data for Ti6Al4V alloy base and coated samples after immersing in (SBF) solution for two weeks. 


\begin{tabular}{|c|c|c|c|c|c|c|c|c|c|}
\hline ITEM & $\begin{array}{l}\text { Magnitude } \\
|\mathrm{Z}| 0.01 \mathrm{~Hz} \\
\left(\mathrm{k} \Omega . \mathrm{cm}^{2}\right)\end{array}$ & $\begin{array}{l}\text { Rs } \\
\Omega . \mathrm{cm}^{2}\end{array}$ & $\begin{array}{l}\mathrm{C}_{\text {coat }} \\
\mu \mathrm{F} / \mathrm{cm}^{2}\end{array}$ & $n$ & $\begin{array}{l}R_{\text {coat }} \\
k \Omega . \mathrm{cm}^{2}\end{array}$ & $\begin{array}{l}C_{d l} \\
\mu F / \mathrm{cm}^{2}\end{array}$ & $n$ & $\begin{array}{l}\mathrm{R}_{\mathrm{dl}} \\
\mathrm{k} \Omega . \mathrm{cm}^{2}\end{array}$ & $\chi^{2}$ \\
\hline uncoat & 3.692 & 994 & 166.7 & 0.53 & 3.186 & 290.2 & 0.52 & 9.820 & 0.14 \\
\hline $\begin{array}{l}2 \mathrm{gm} \\
\text { coll. }\end{array}$ & 16.143 & 677 & 110.1 & 0.49 & 4.821 & 170.3 & 0.48 & 16.270 & 0.12 \\
\hline $\begin{array}{l}4 \mathrm{gm} \\
\text { coll. }\end{array}$ & 18.663 & 404 & 86.6 & 0.51 & 5.021 & 135.7 & 0.49 & 19.580 & 0.15 \\
\hline $\begin{array}{l}6 \mathrm{gm} \\
\text { coll. }\end{array}$ & 45.394 & 524 & 62.3 & 0.48 & 6.728 & 60.5 & 0.53 & 25.330 & 0.13 \\
\hline
\end{tabular}

\section{Conclusion:}

From previous results we conclude that the collagen make good agglomeration between the particles themselves and good adhesion between the coated layer and the Ti-6Al-4V alloy. More quantity of collagen led to more formation of the hydroxyapatite (i.e more osseointegration), and led to enhance corrosion characteristics. The best results obtained with $6 \mathrm{gm}$ collagen coated sample.

\section{References}

1. M. - Ramón Rial, Z. González-Durruthy, Liu, M. Juan, Ruso." Advanced Materials Based on Nanosized Hydroxyapatite" Molecules,2021, 26, 3190

2. S.Uz Zaman, M. Irfan, M. Irfan, N. Muhammad, M. Khaliq, U. Zaman, Abdur Rahim and Saif-UrRehman " Overview of hydroxyapatite; composition, structure, synthesis methods and its biomedical uses ". Biomedical Letters 6(1), 84-99 (2020)

3. M.M.Q. Nawaz, M.AtiqU.R.M. Cresswell ,Phil K. Jackson, R. Hurle, H. Detsch, Wolfgang, Goldmann, Asma Tufail Shah and Aldo R. Boccaccini ." Variation of crystal structure of hydroxyapatite in calcium phosphate cement by the substitution of strontium ions", Int. J. Mol. Sci. 2021, 22, 4246

4. Corina Garbo, J. Locs,Matteo, D.'Este,G. Demazeau, A.M.C. Roman, Ossi Horovitz, Maria TomoaiaCotisel " Advanced Mg, Zn, Sr, Si Multi-Substituted Hydroxyapatites for Bone Regeneration", International Journal of Nanomedicine 2020:15 1037-1058

5. Rinaldo Florencio-Silva, Gisela Rodrigues da Silva Sasso, Estela Sasso-Cerri, Manuel Jesus Simões and Paulo Sérgio Cerri "Biology of Bone Tissue: Structure, Function, and Factors That Influence Bone (Cells" BioMed Research International Volume, 2015)

6. W.D. -, H. Czernuszka, " Collagen-Hydroxyapatite Composites for Hard Tissue Repair". Europ. Cell. Mater., 2006,11,43-56

7. Q. - Chen. C. Zhu, G.A. Thouas, Progress and challenges in biomaterials used for bone tissue engineering: bioactive glasses and elastomeric composites ". Prog. i Biomater. 1(2), 1-22 (2012) 
8. R.A. - Hitti, D.G. Kerns, " Guided Bone Regeneration in the Oral Cavity: A Review ", Open Patho. J. 5, 33-45 (2012)

9. W. Wang, Q.M.Q. Li, J. Liu, M. Zhou, Zheng Jin and Kai Zhao "Chitosan Derivatives and Their Application in Biomedicine" Int. J. Mol. Sci. 21, 487 (2020)

10. W. Klongthong, Veera Muangsin, Chupun Gowanit, and Nongnuj Muangsin "Chitosan Biomedical Applications for the Treatment of Viral Disease: A Data Mining Model Using Bibliometric Predictive Intelligence" Journal of Chemistry,Volume 2020

11. M. -Areli, Salgado-Delgado, Heriberto Hernández-Cocoletzi, Efrain Rubio-Rosas, Alejandro EscobedoMorales, Ernesto Chigo-Anota, Alfredo Olarte-Paredes,Rene Salgado-Delgado and Victor M. Castaño " Simulated body fluid nucleation of poly(vinyl alcohol)/nanohydroxyapatite hydrogels"Polimery 2019, 64, $\mathrm{nr} 7-8$

12. L. - Martina. P. Eva, S. Jordi, D.B. Maria, K. Janez, Sasa N. and Spomenka K. "Improvement to the Corrosion Resistance of Ti-Based Implants Using Hydrothermally Synth-esized Nanostructured Anatase Coatings" Mat. 2014, 7, 180-194

13. A. Gallegos-Melgar, S.A. Serna, I. Lázaro, E.-J. Gutiérrez-Castañeda, ,V.H. Mercado-Lemus, H. ArcosGutierrez, M. Hernández-Hernández ,J. Porcayo Calderón, J. Mayen and M. Del Angel Monroy " Potentiodynamic Polarization Performance of a Novel Composite Coating System of Al203/Chitosan-Sodium Alginate, Applied on an A.A.6063 Aluminum, Alloy for Protection in a Chloride lons. Environment " Coatings 10, 45 (2020)

\section{Figures}
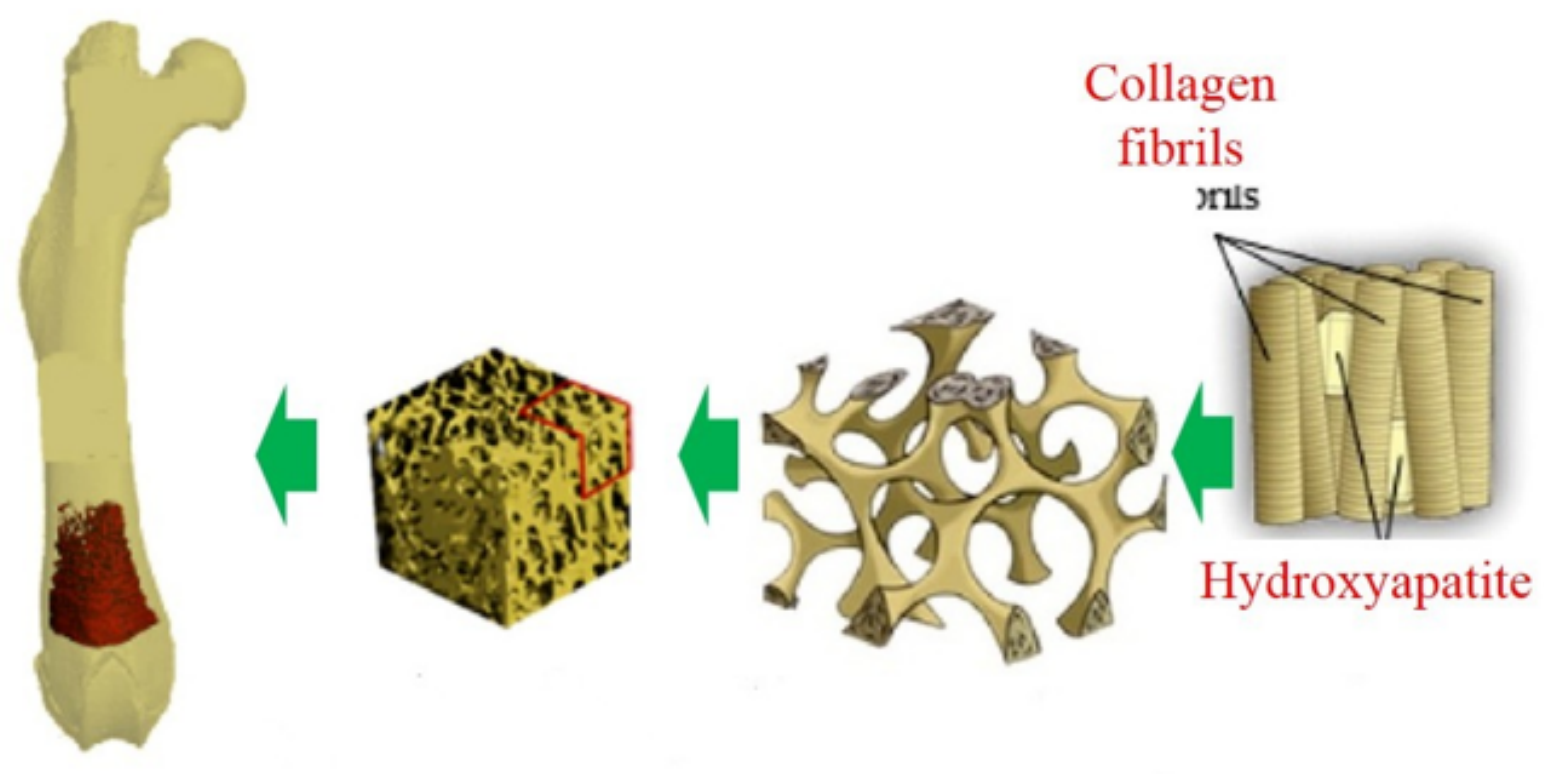

Ultra-structure

Micro-structure

Nano-structure

Composition

Scale: $5 \mathrm{~mm}$ Scale: $10 \mu \mathrm{m}$ Scale: $-500 \mathrm{~nm}$

Scale: $+5 \mathrm{~nm}$ 
Figure 1

Hierarchical structure of bone.

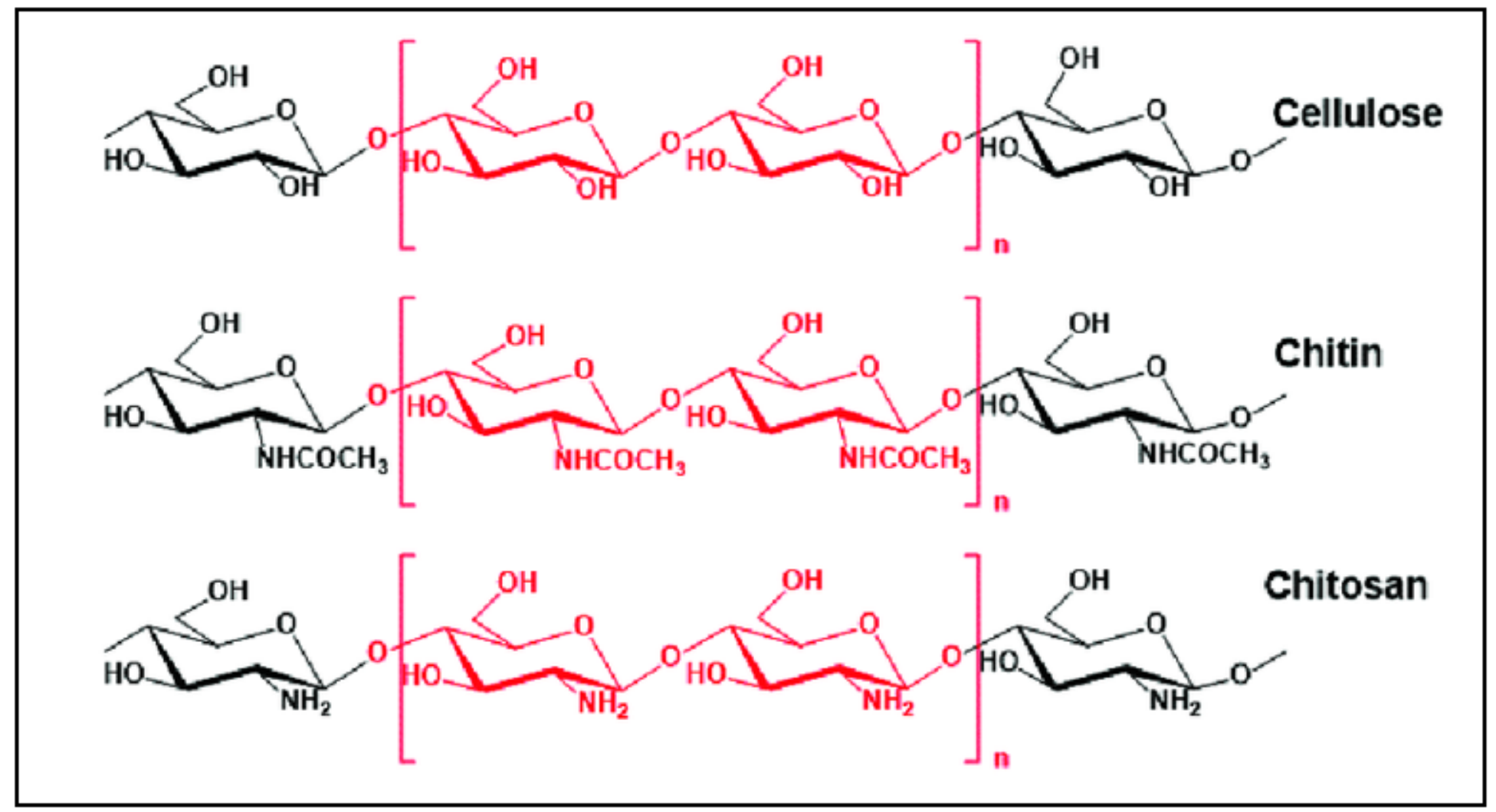

Figure 2

Structures of chitin, chitosan, and cellulose. 


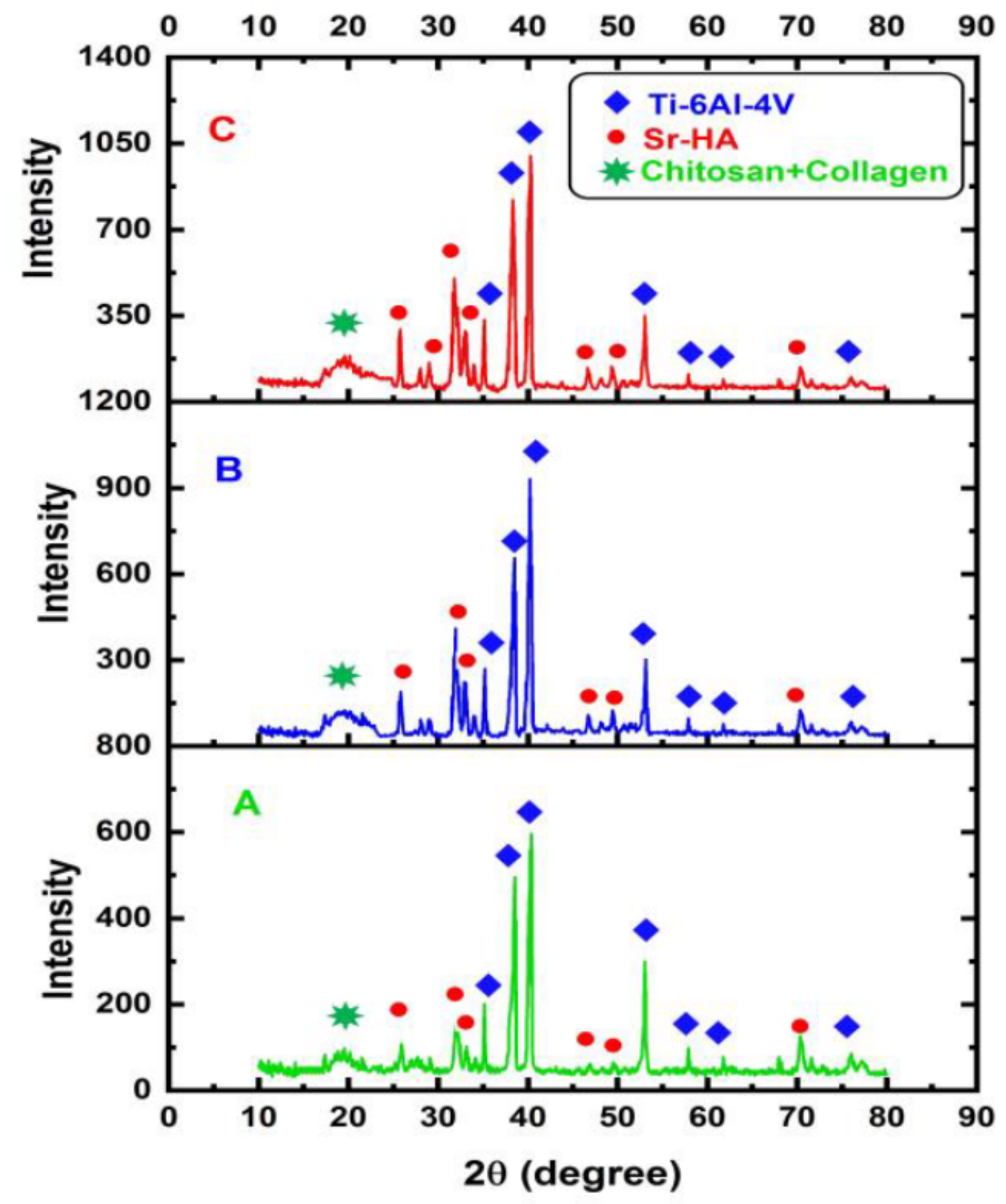

Figure 3

XRD patterns for Ti-6Al-4V samples coated with SrHA - collagen and different chetosan quantity (A): $3 g m$ (B): $6 \mathrm{gm}$ and (C): $9 \mathrm{gm}$. 


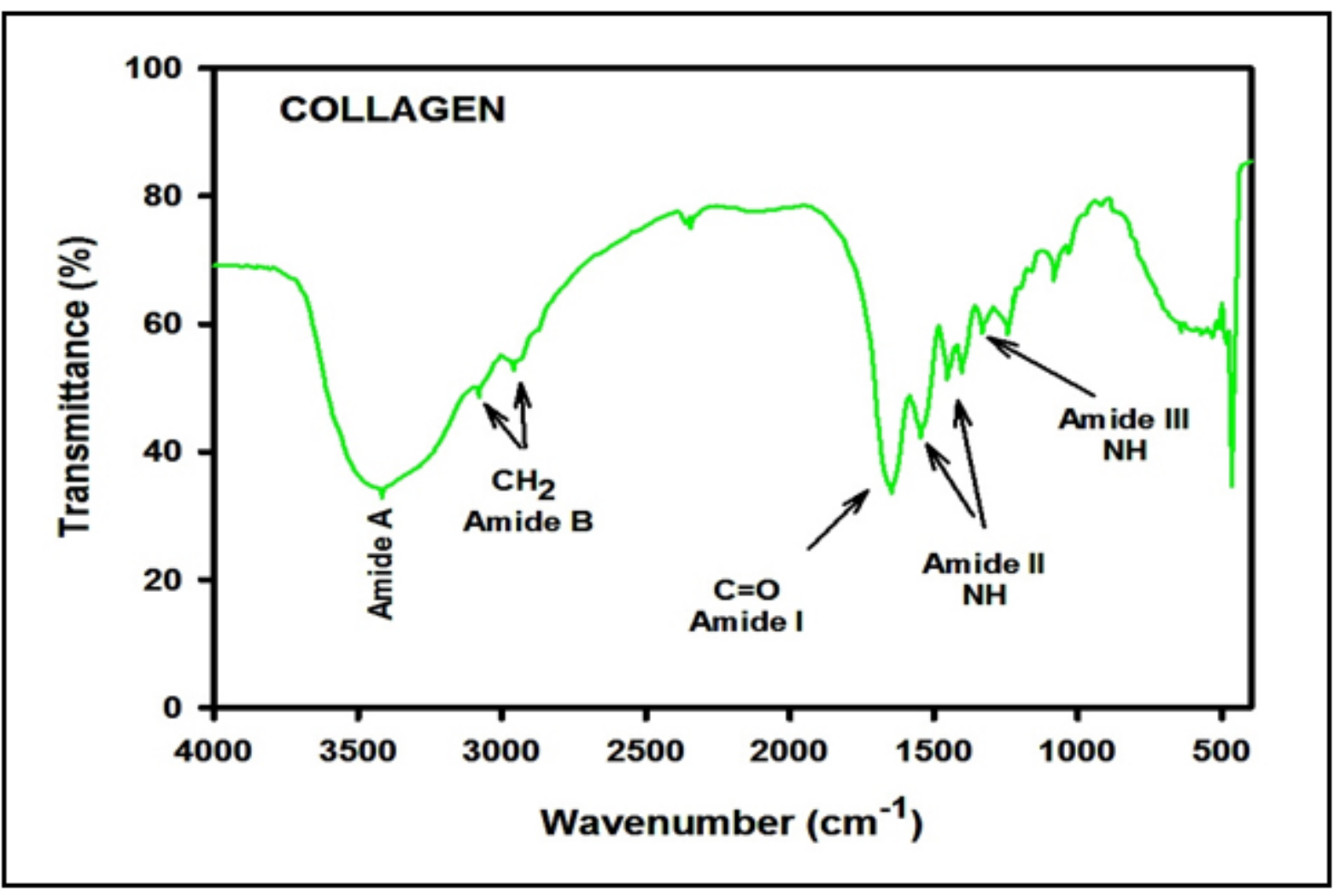

Figure 4

FTIR spectrum for collagen.

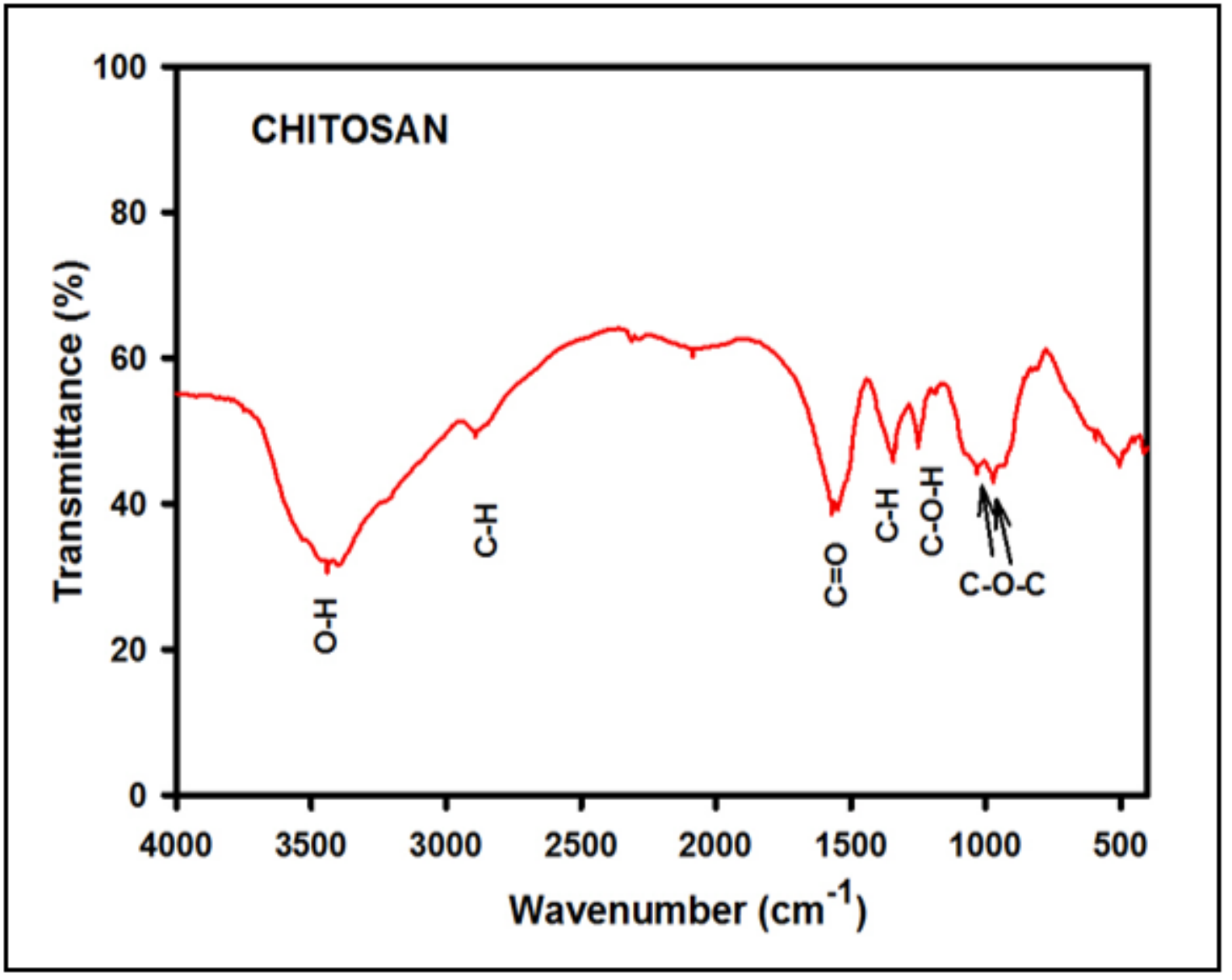


Figure 5

FTIR spectrum of chitosan.

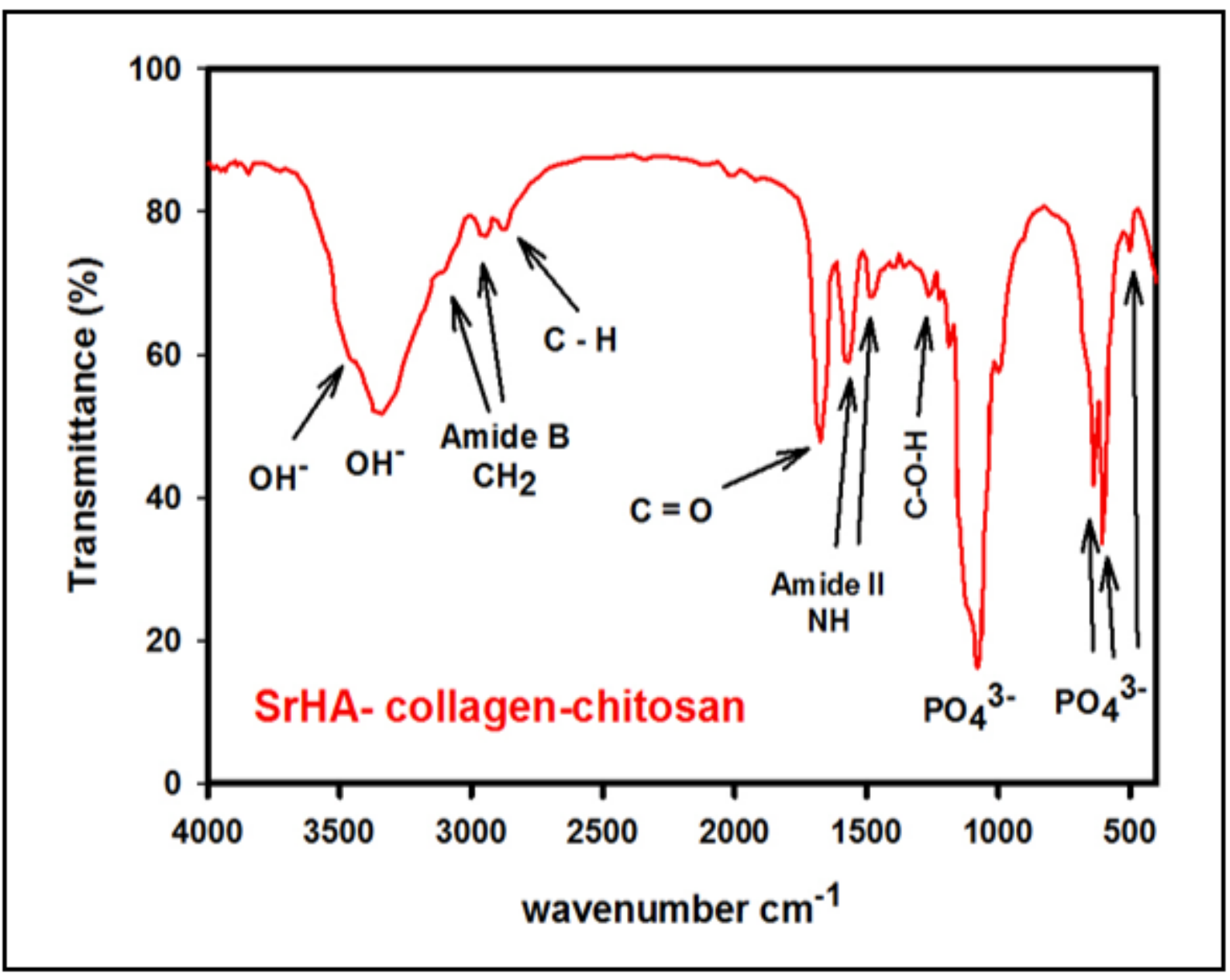

Figure 6

FTIR spectrum for SrHA-collagen- 

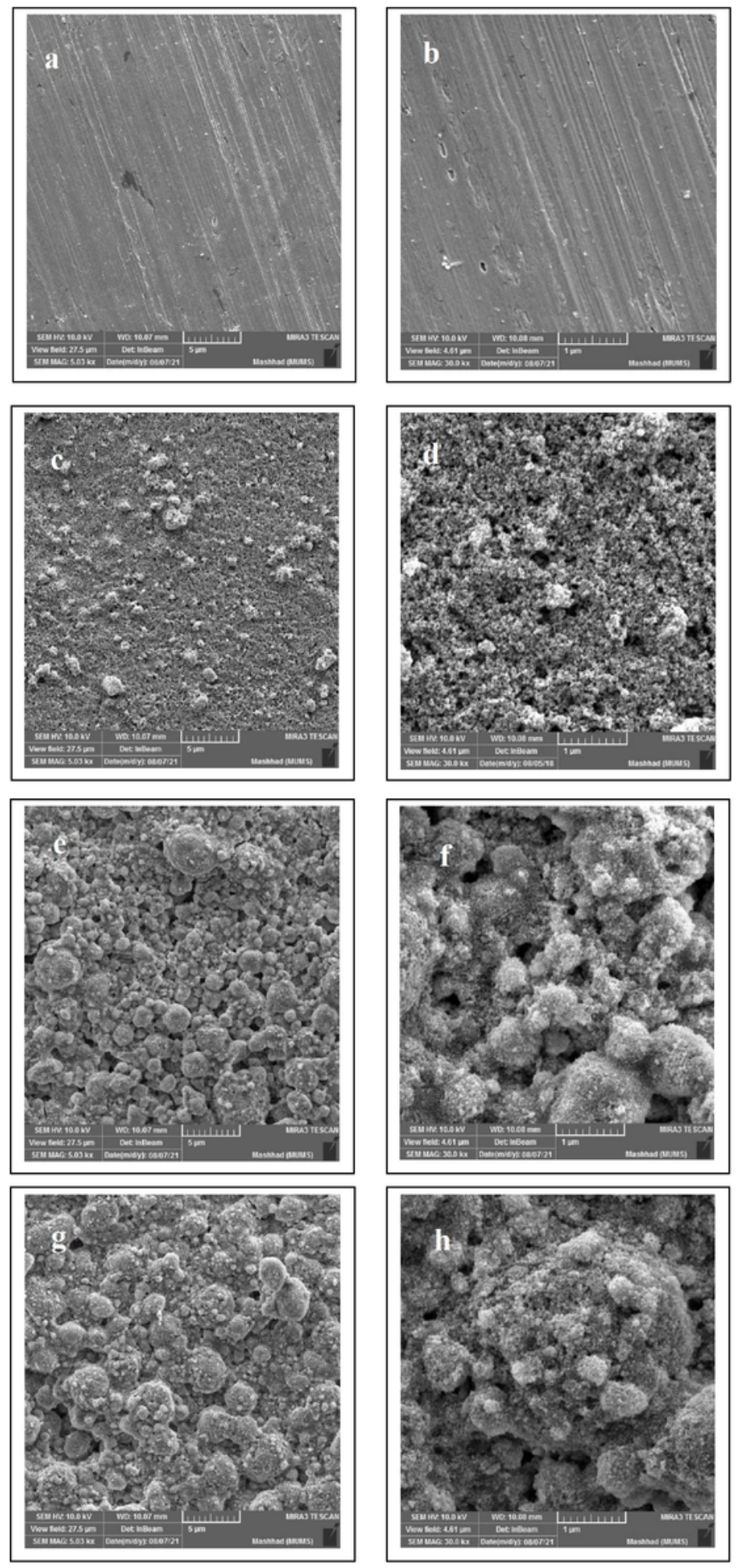

Figure 7

SEM test images for Ti-6Al-4V alloy coated with SrHA-chitosan and different quantity of collagen (a and b): uncoated base alloy, (c and d): $2 \mathrm{gm}$ collagen, (e and f): $4 \mathrm{gm}$ collagen and ( $\mathrm{g}$ and h): $4 \mathrm{gm}$ collagen. 


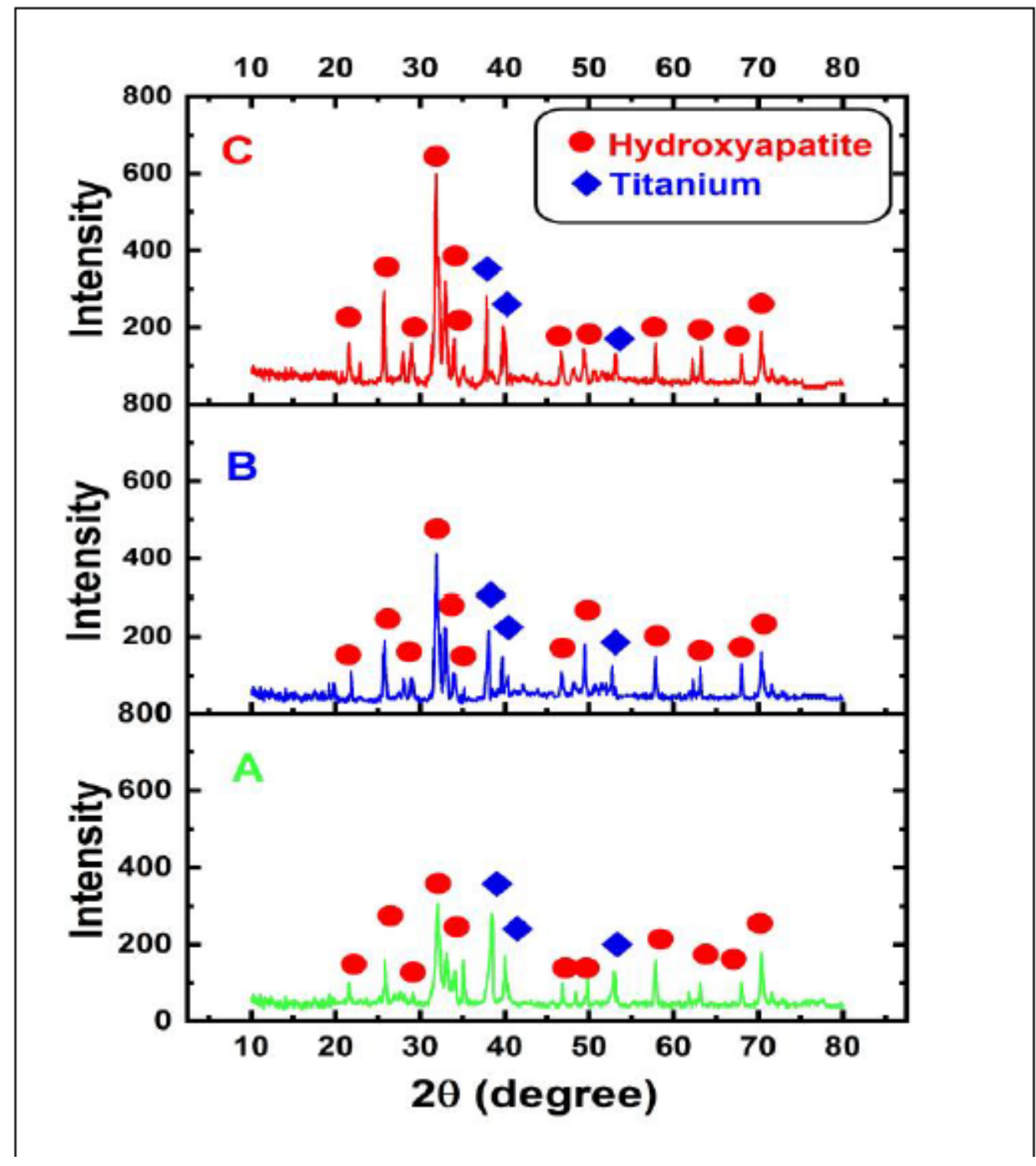

Figure 8

XRD pattern for Ti-6Al-4V alloy coated with SrHA- chitosan - collagen after immersing in SBF for two weeks a:2gm collagen, b:4 gm collagen, c:6gm collagen. 


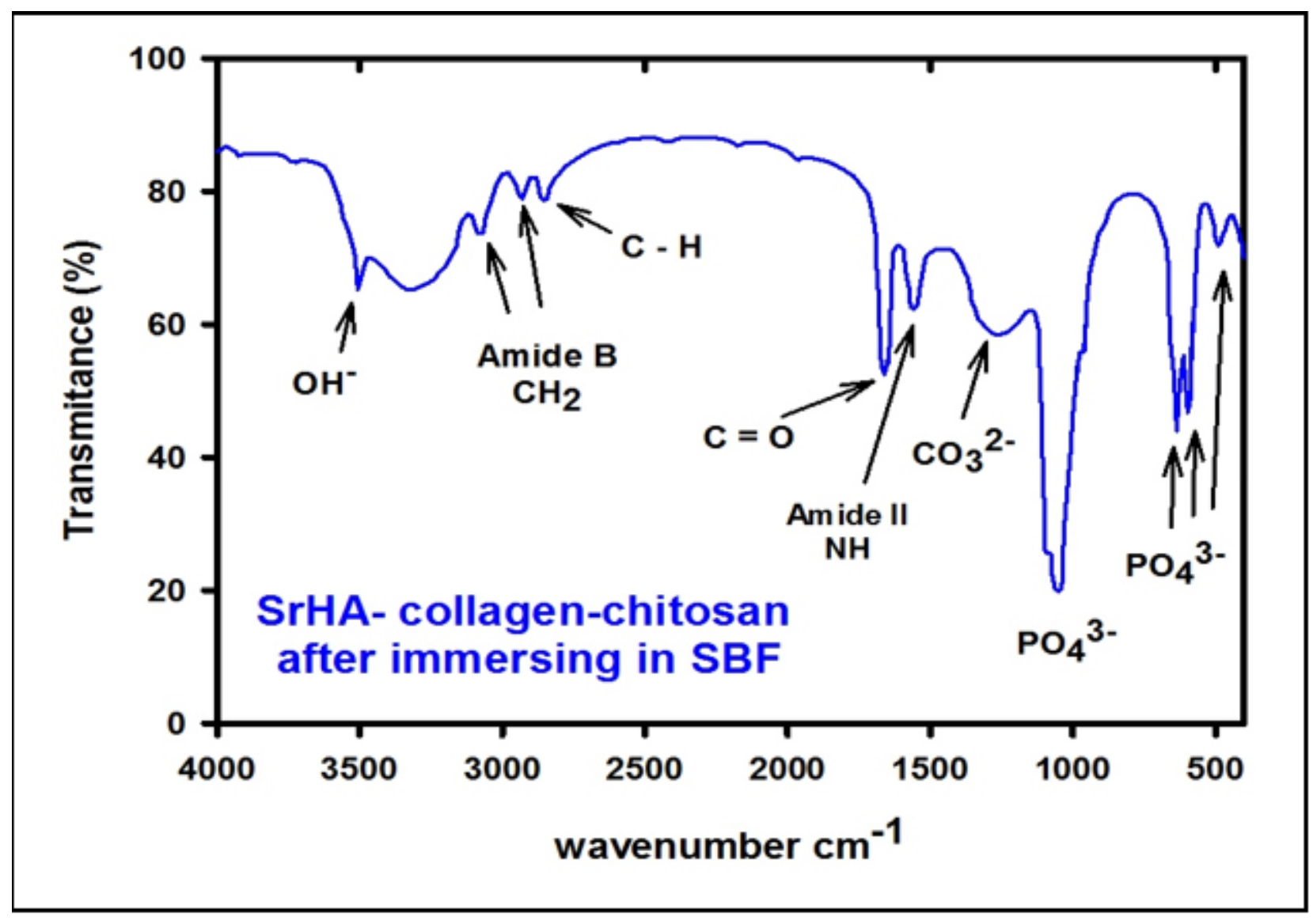

Figure 9

FTIR spectrum for Ti-6Al-4V coated with SrHA - chitosan - collagen after immersing in SBF for two weeks. 

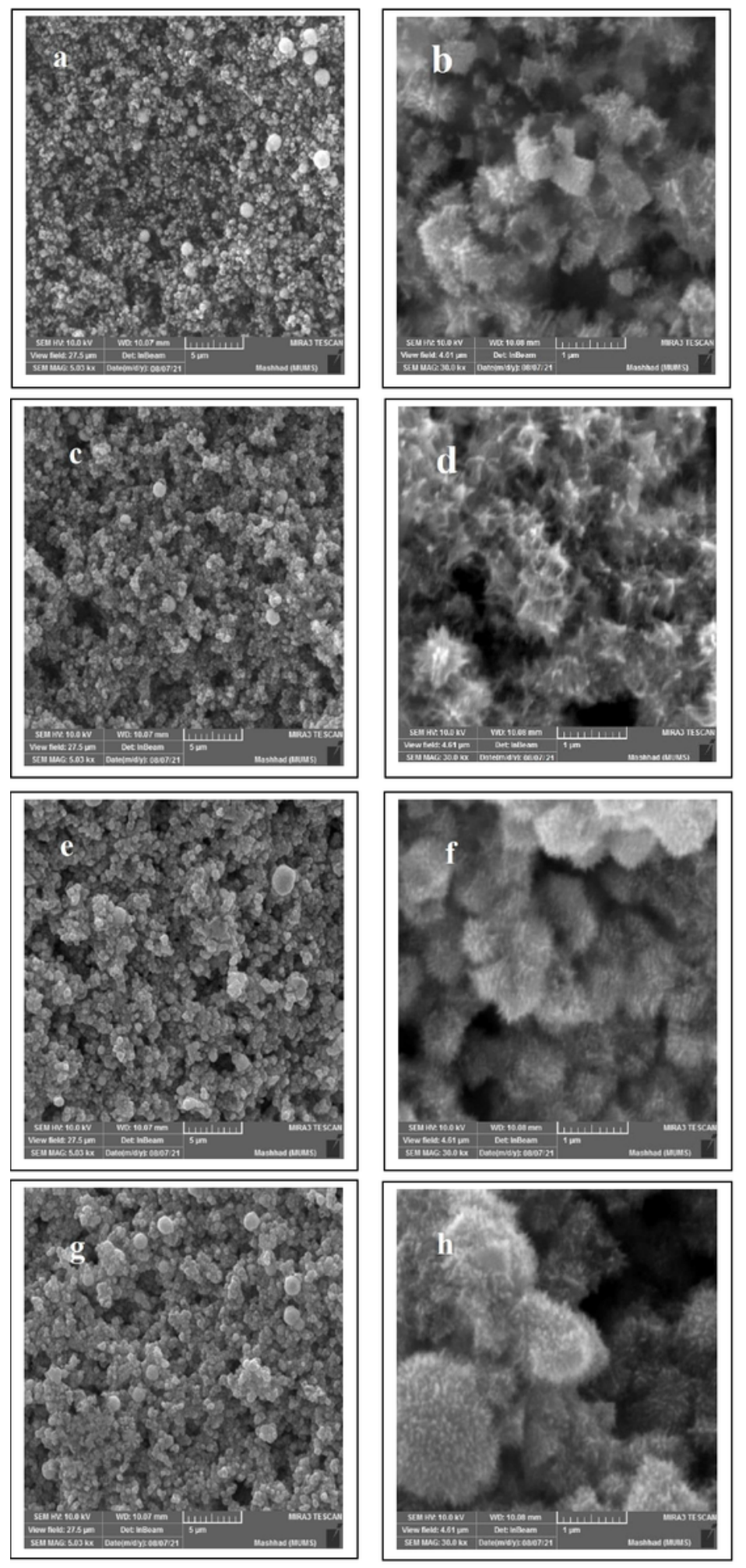

Figure 10

SEM test image for Ti-6Al-4V alloy coated with SrHA- chitosan - collagen after immersing in SBF for two weeks ( $a$ and $b$ ): uncoated, ( $c$ and d): 2 gm collagen, (e and f): $4 \mathrm{gm}$ collagen and ( $g$ and $h$ ): $6 \mathrm{gm}$ collagen. 


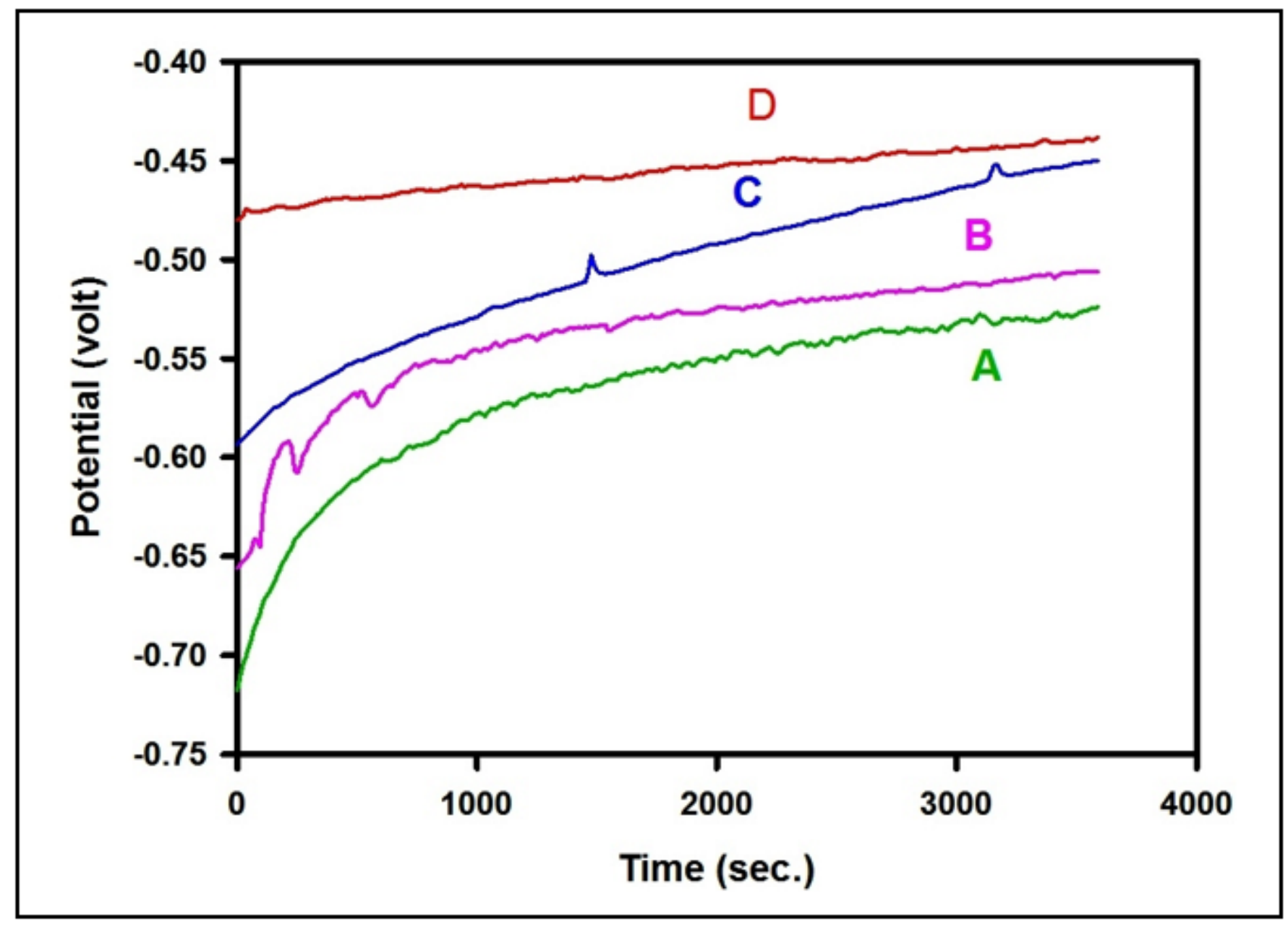

Figure 11

OCP test for sample coated with with SrHA- chitosan - collagen (a): uncoated, (b): 2 gm collagen, (c):4gm collagen and (d): $6 \mathrm{gm}$ collagen. 


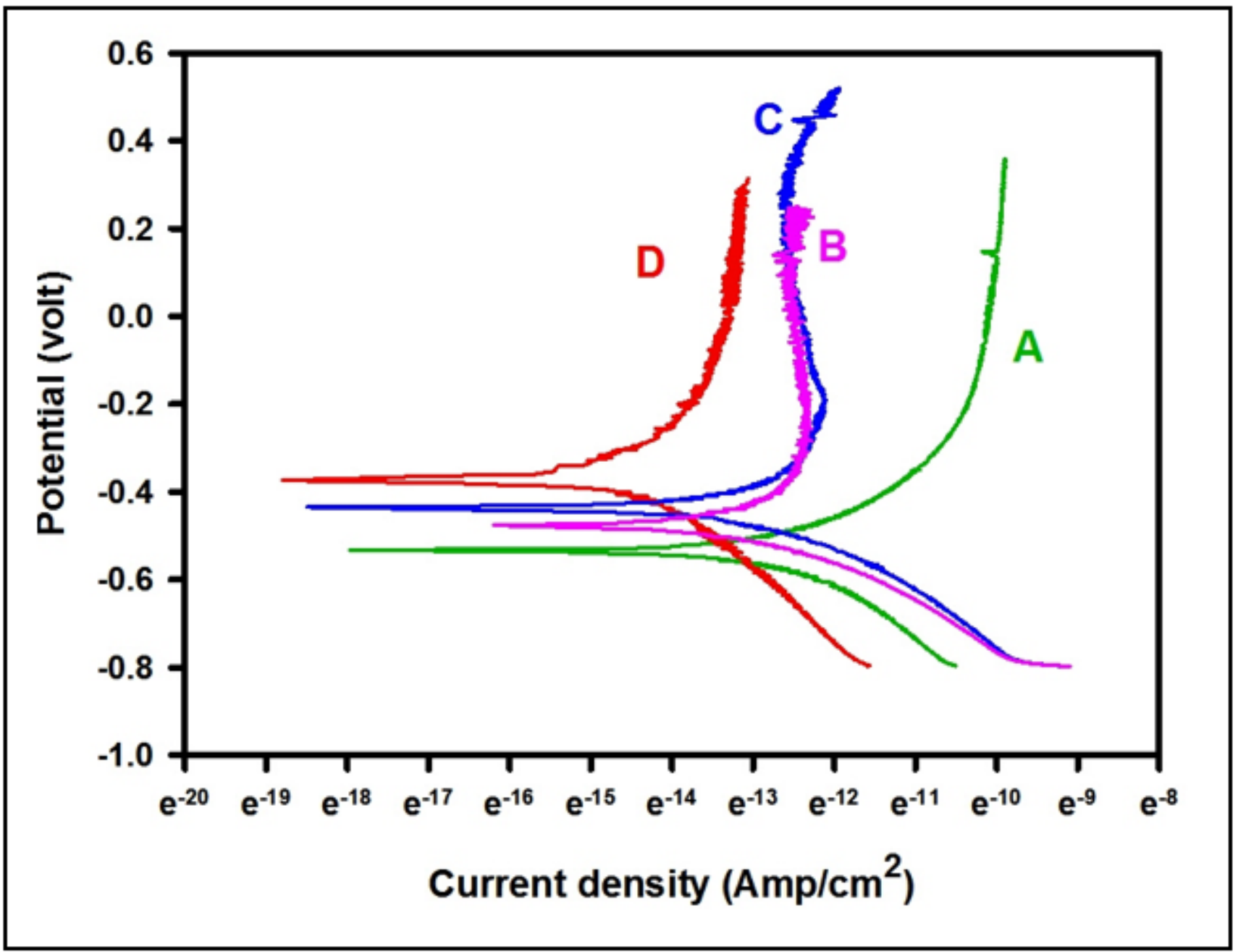

Figure 12

Polarization curve for sample coated with SrHA- chitosan - collagen (a): uncoated, (b): 2gm collagen, (c):4gm collagen and (d): $6 \mathrm{gm}$ collagen. 


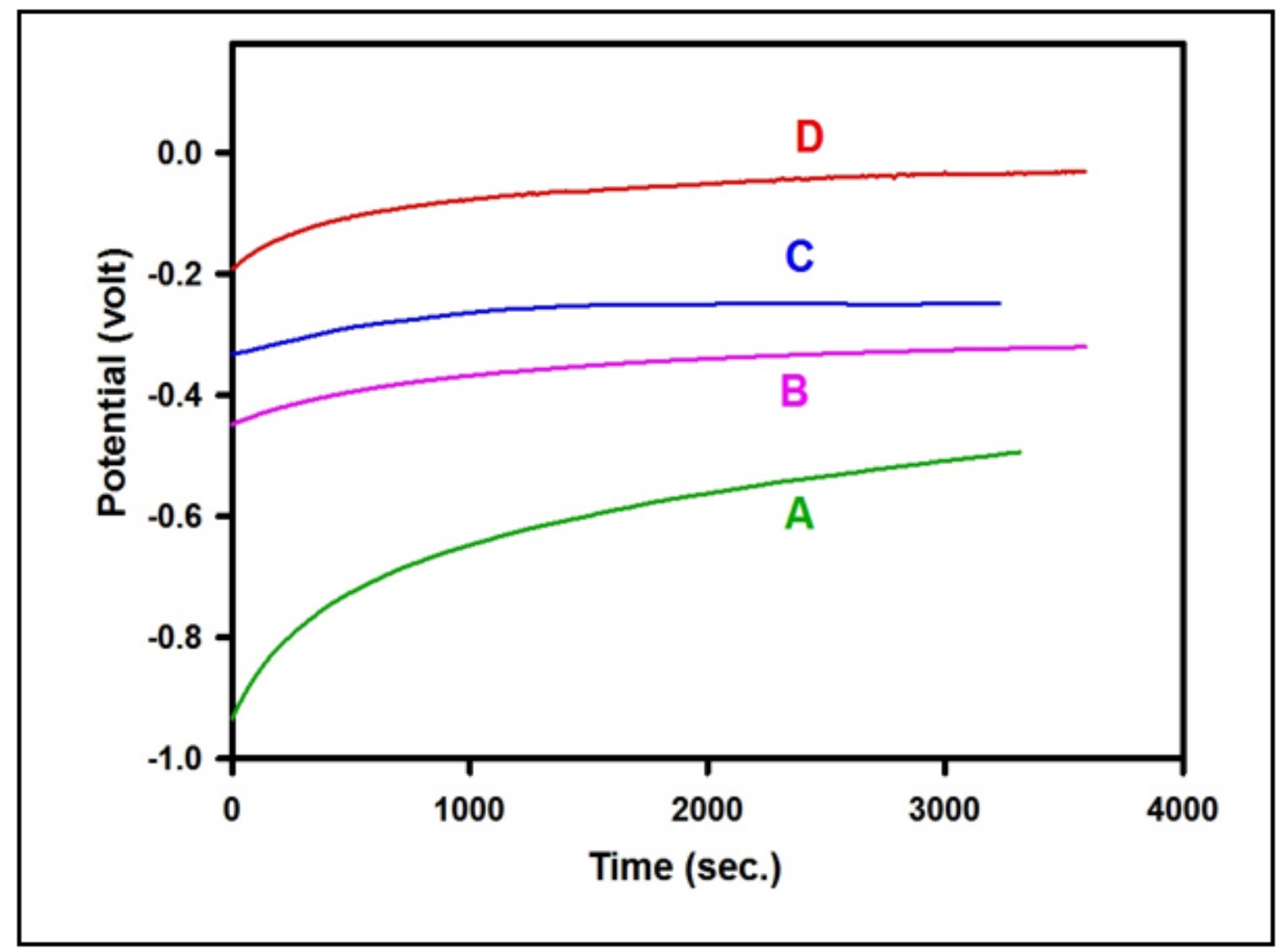

Figure 13

OCP test for sample coated with SrHA- chitosan - collagen after immersing in SBF solution for two weeks (a): uncoated, (b): $2 \mathrm{gm}$ collagen, (c):4gm collagen and (d): $6 \mathrm{gm}$ collagen. 


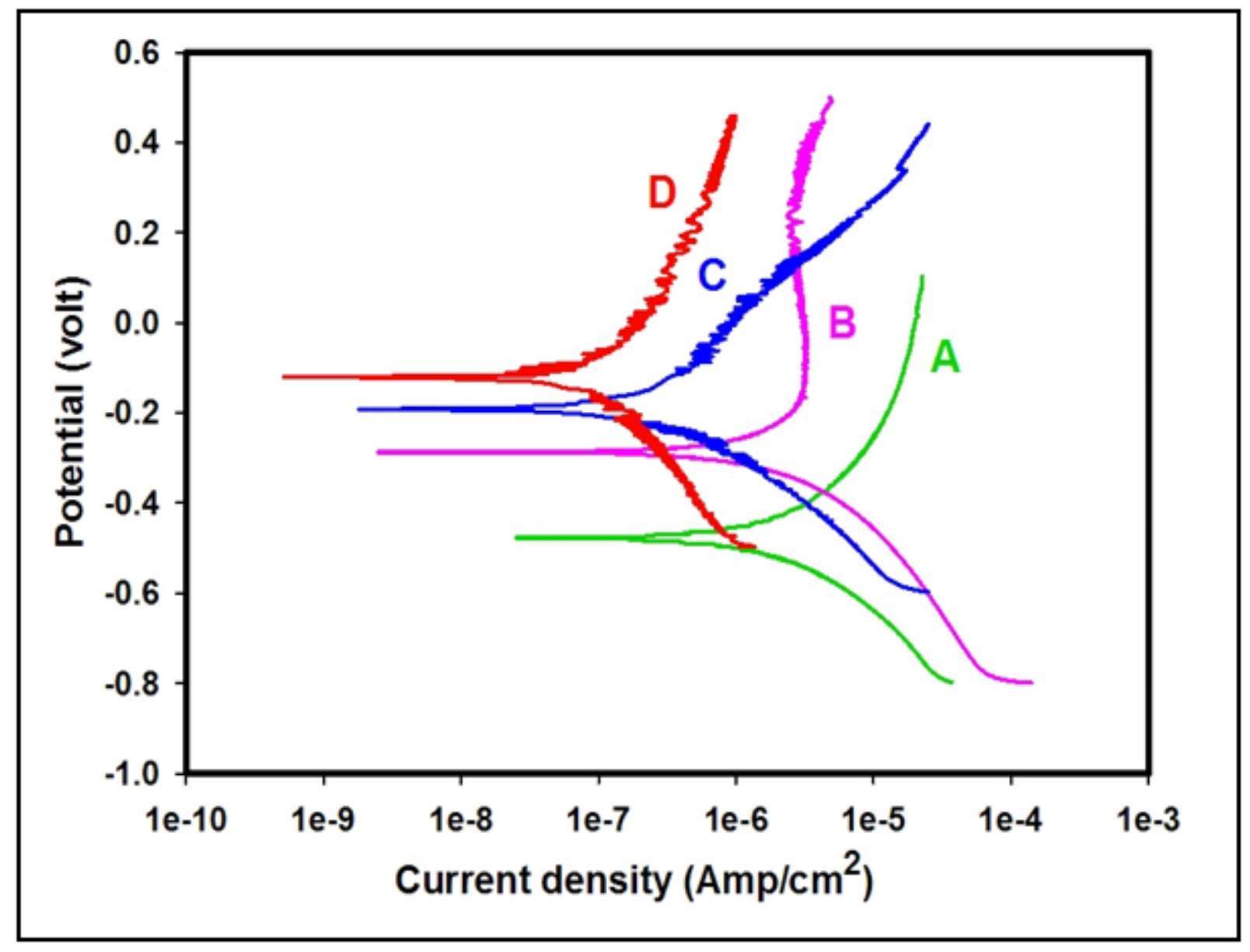

\section{Figure 14}

Polarization curve tafel test for sample coated with SrHA- chitosan - collagen after immersing in SBF solution for two weeks (a): uncoated, (b): $2 \mathrm{gm}$ collagen, (c):4gm collagen and (d): $6 \mathrm{gm}$ collagen.

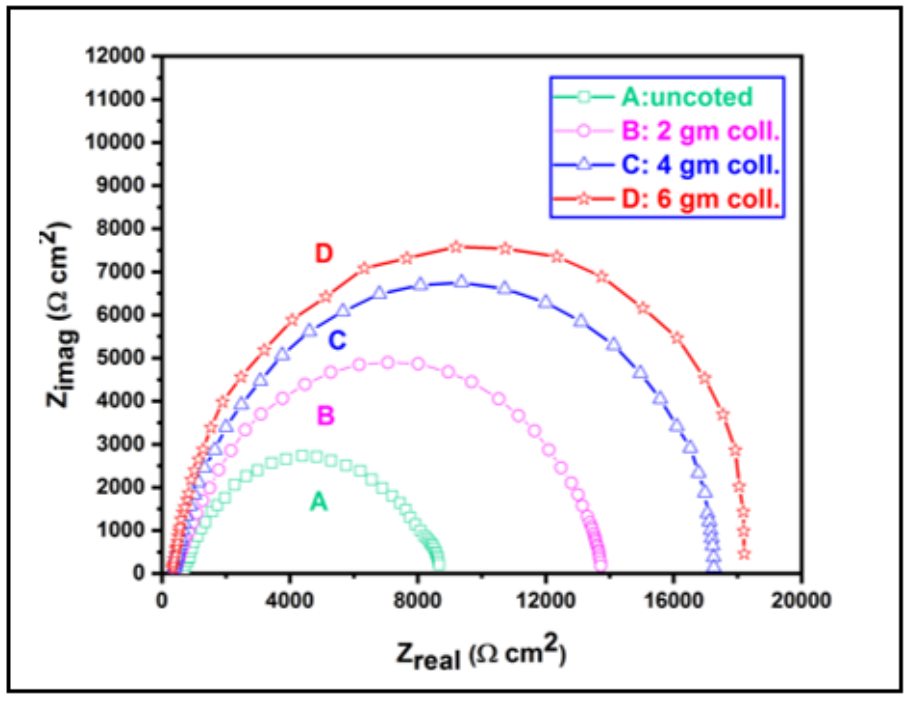

(a)

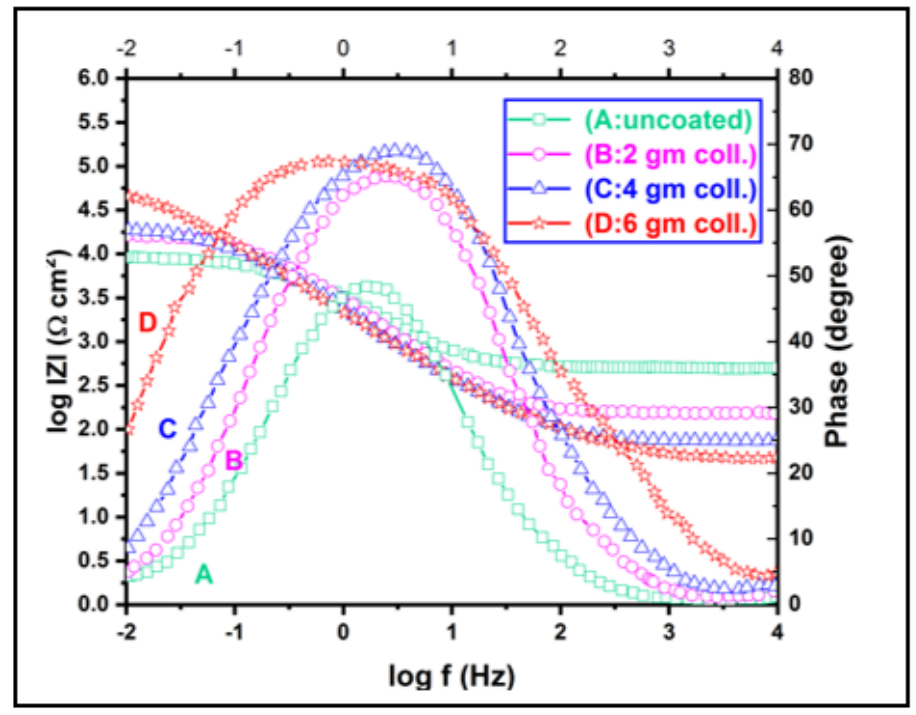

(b)

Figure 15 
(a) nyquist and (b) bode plot for Ti6Al4V samples coated with different collagen quantity.
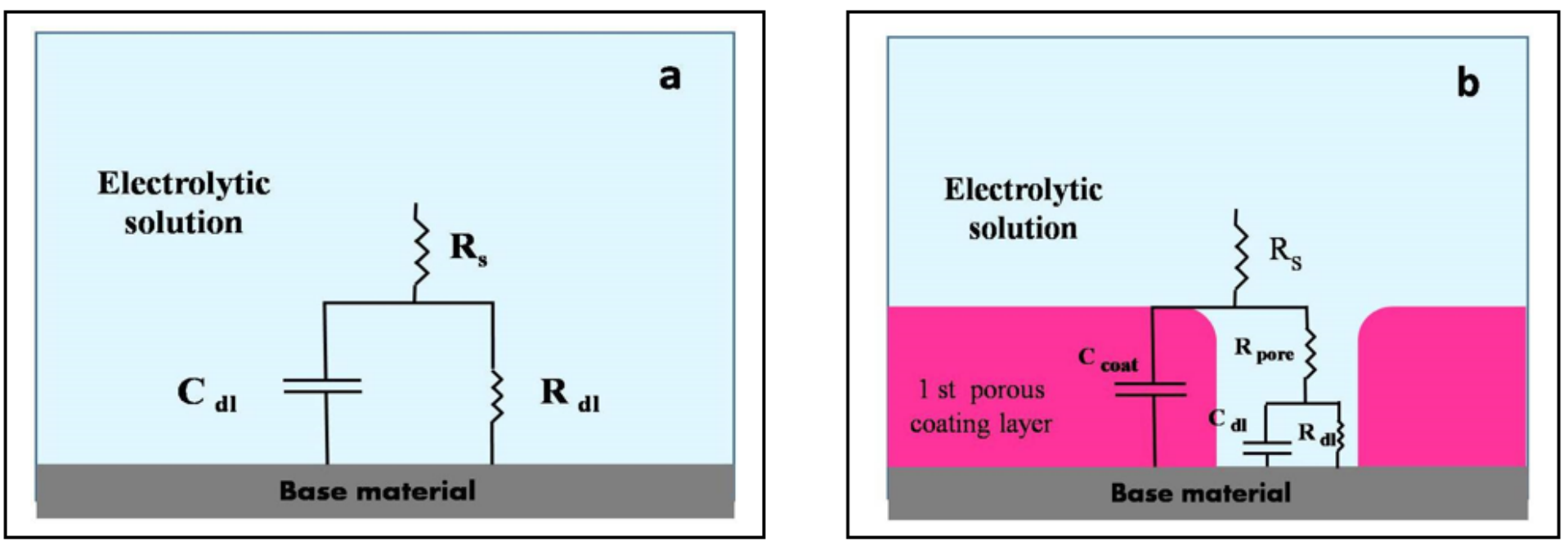

Figure 16

Equivalent circuit used in data fitting for Ti6Al4V alloy (a) base and (b) coated samples.

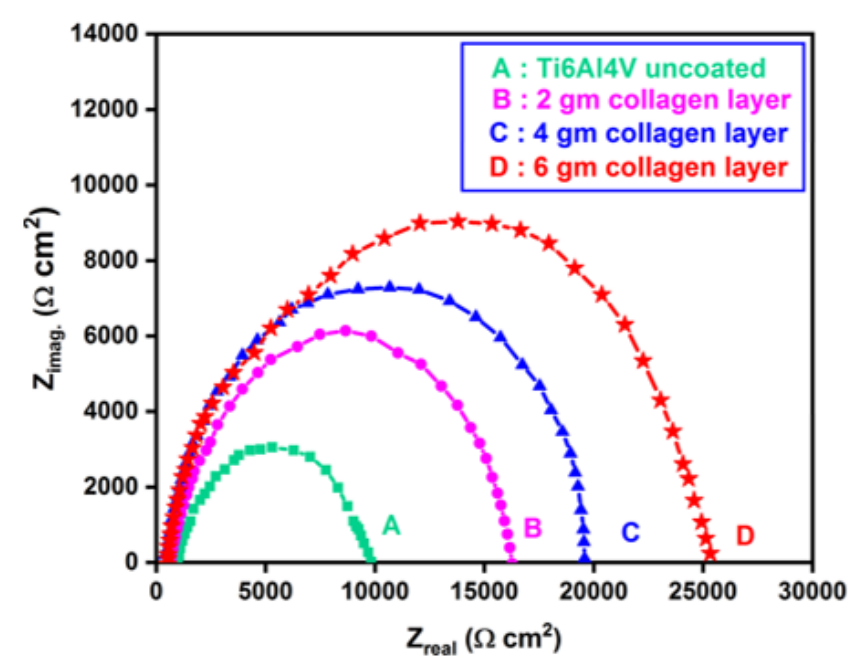

(a)

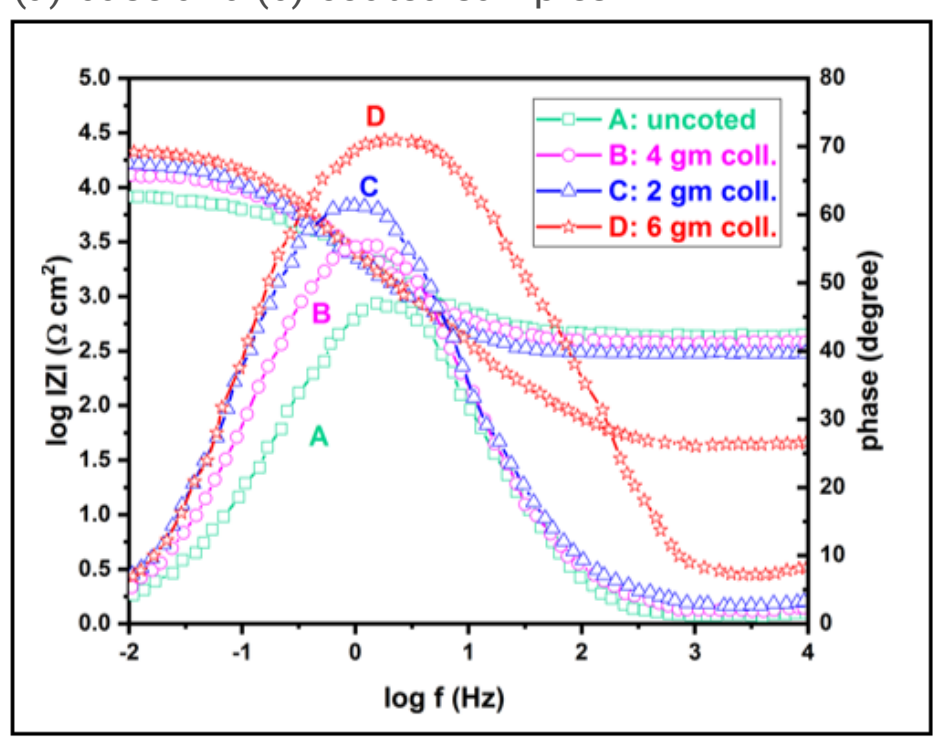

(b)

Figure 17

(a) nyquist and (b) bode plot for Ti6Al4V samples coated with different collagen quantity after immersing in (SBF) solution for two weeks. 


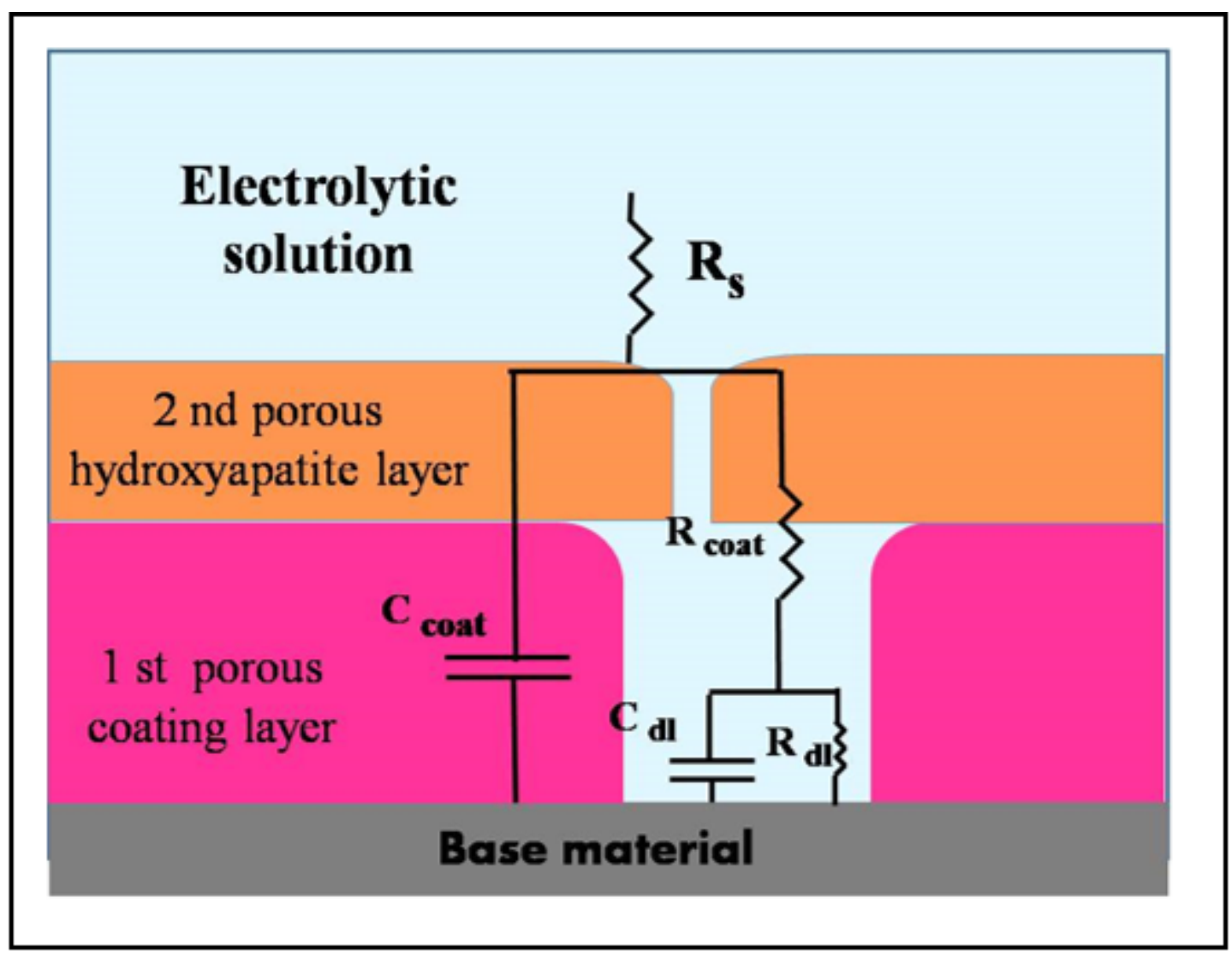

Figure 18

Equivalent circuit used in data fitting for Ti6Al4V alloy) coated samples after immersing in (SBF) solution. 